\title{
Penerapan Model Project Based Learning untuk Meningkatkan Minat dan Hasil Belajar IPS
}

\author{
Hadi Sucipto $^{(1)}$ \\ ${ }^{1}$ SMK Negeri 3 Blitar,
}

\begin{abstract}
ABSTRAK
Penelitian ini bertujuan untuk meningkatkan minat dan hasil belajar siswa kelas XI IPS 5 SMAN 3 Blitar melalui penerapan model project based learning. Subyek penelitiam ini adalah siswa kelas XI IPS 5 SMAN 3 Blitar dengan jumlah 28 siswa. Penelitian ini merupakan Penelitian Tindakan Kelas (PTK) dengan pendekatan kualitatif deskriptif yang dilakukan dalam dua siklus. Tiap siklus dalam penelitian ini terdiri dari empat tahap yaitu: (1) perencanaan, (2) pelaksanaan, (3) pengamatan, dan (4) refleksi. Instrumen yang digunakan adalah tes hasil belajar dan observasi. Hasil penelitian menunjukkan bahwa dengan menggunakan model project based learning dapat meningkatkan minat belajar yang dilihat melalui aktivitas belajar siswa untuk setiap kelompok. Project based learning juga dapat meningkatkan hasil belajar secara klasikal dari siklus I hasil belajar siswa mencapai $61 \%$ dan pada siklus II mencapai $71 \%$..
\end{abstract}

\section{Kata kunci: Model Project Based Learning, Minat Belajar, Hasil Belajar.}

\section{PENDAHULUAN}

Pembelajaran kurikulum 2013 adalah pembelajaran kompetensi dengan memperkuat proses pembelajaran dan penilaian autentik untuk mencapai kompetensi sikap, pengetahuan dan keterampilan. Prinsip pembelajaran pada kurikulum 2013 menekankan perubahan paradigma dari pembelajaran yang berpusat pada guru (Teacher Centered) menjadi pembelajaran yang berpusat pada siswa (Student Centered), pembelajaran yang sebelumnya bersifat verbalisme menjadi aplikatif serta proses belajar dapat berlangsung di rumah, di sekolah, dan di masyarakat.

Berdasarkan hasil observasi peneliti di kelas XI IPS 5 SMAN 3 Blitar dapat diperoleh hasil sebagai berikut: (1) minat dan kesadaran siswa untuk belajar masih rendah dibuktikan dengan beberapa siswa masih sering berbicara sendiri saat pelajaran berlangsung dan apabila diberi pertanyaan tidak dapat menjawab, (2) model pembelajaran yang digunakan oleh guru mata pelajaran itu sendiri kurang bervariasi, (3) siswa pasif dalam proses pembelajaran, dan (4) hasil belajar siswa masih rendah atau kurang dari KKM. Dari beberapa hasil yang diperoleh diatas, mengakibatkan siswa cenderung jenuh dan bosan saat pembelajaran berlangsung karena guru hanya menyampaikan dan menjelaskan materi di depan kelas saja. Perhatian guru pun tidak dapat sepenuhnya kepada siswa. Siswa hanya duduk dan mendengarkan guru menyampaikan materi dan tidak ikut berperan aktif saat proses pembelajaran berlangsung. Hasil belajar pada mata pelajaran Akuntansi dari 28 siswa terdapat sekitar $78 \%$ siswa belum mencapai KKM dan harus mengikuti ujian remedial. Ujian remedial dilaksanakan karena tidak semua siswa memperoleh nilai yang sesuai dengan KKM yaitu 70.

Agar tercapai tujuan yang ingin dicapai pada implementasi kurikulum 2013 maka dilaksanakan dengan menggunakan pendekatan ilmiah (Scientific Approach), yaitu pembelajaran yang mendorong siswa lebih baik dalam melakukan pengamatan/observasi,bertanya, bernalar, mencoba dan mengomunikasikan/ mempresentasikan (Maulipaksi, 2014; EH, 2013). Salah satu model pembelajaran yang dianggap dapat meningkatkan minat belajar siswa untuk mengikuti proses pembelajaran dengan baik dan meningkatkan pemahaman siswa mengenai materi akuntansi adalah model pembelajaran berbasis proyek atau project based learning. Pembelajaran berbasis proyek merupakan pendekatan pendidikan yang berfokus pada kreatifitas berfikir, pemecahan masalah, dan interaksi antara siswa dengan kawan 
sebaya untuk menciptakan dan menggunakan pengetahuan baru (Berenfeld dalam Rais, 2010). Thomas (2000) mengemukakan bahwa prinsip pembelajaran berbasis proyek pada prosesnya mengarah kepada pencapaian tujuan, yang mengandung kegiatan inkuiri, pembangunan konsep, dan resolusi. Selain itu juga memuat proses perancangan, pembuatan keputusan, penemuan masalah, pemecahan masalah, discovery dan pembentukan model.

Penerapan model pembelajaran project based learning dalam pembelajaran ini memiliki tujuan untuk meningkatkan minat belajar siswa sehingga diharapkan juga hasil belajar yang didapatkan siswa maksimal. Minat Menurut Hidi \& Harackiewicz (2000) , siswa yang tertarik pada apa yang mereka pelajari menunjukkan prestasi akademik yang lebih tinggi dan lebih mungkin mengingat materi tersebut dalam jangka panjang. Seringkali minat dan pengetahuan saling menguatkan : minat dalam sebuah topik tertentu memicu semangat untuk mempelajari lebih dalam tentang topik tersebut , dan pengetahuan bertambah sebagai akibat dari proses pembelajaran itu pada gilirannya akan meningkatkan minat yang lebih besar lagi (Blumenfeld dalam Ormrod, 2009: 102). Tujuan penelitian ini adalah untuk mengetahui peningkatan minat belajar dan hasil belajar akuntansi siswa yang diberikan pembelajaran dengan menerapkan model project based learning.

\section{METODE}

Jenis penelitian ini menggunakan Penelitian Tindakan Kelas (PTK) karena dilakukan didalam kelas untuk memberikan tindakan tertentu agar dapat memperbaiki proses pembelajaran di kelas. Pendekatan penelitian ini menggunakan pendekatan kualitatif deskriptif. Menurut Sugiyono (2008:15) pendekatan kualitatif deskriptif adalah metode penelitian yang berlandaskan pada filsafat postpositivisme yang biasanya digunakan untuk meneliti pada kondisi objektif yang alamiah dimana peneliti berperan sebagai instrumen kunci. Subjek dalam penelitian ini adalah siswa kelas XI IPS 5 pada semester genap tahun pelajaran 2016/2017 dengan jumlah 28 orang. Sumber data yang digunakan adalah dari subyek penelitian, guru mata pelajaran, pengamatan, dan dokumentasi. Sedangkan alat yang digunakan adalah rencana pelaksanaan pembelajaran (RPP), lembar observasi, tes, dan dokumentasi. Teknik pengumpulan data pada penelitian ini menggunakan tes tulis dan hasil proyek kelompok siswa berupa makalah untuk mengetahui hasil belajar siswa selain itu juga dilakukan pengamatan minat belajar untuk setiap kelompok mengunakan lembar observasi.

Analisis data yang digunakan adalah metode Miles dan Huberman (dalam Sugiyono, 2009:247), yaitu reduksi data, penyajian data serta kesimpulan dan refleksi. Penelitian tindakan kelas yang digunakan dalam penelitian ini terdiri dari dua siklus. Sedangkan alur rancangan penelitian tindakan kelas ini dikembangkan oleh Kemmis dan Mc Taggart (Uno dkk, 2011:87) yang terdiri dari empat konsep, yaitu: (1) perencanaan, (2) tindakan, (3) pengamatan, dan (4) refleksi.

\section{HASIL}

Berdasarkan data dalam tindakan siklus I, dapat diketahui hasil yang diperoleh sebagai berikut. Penerapan model pembelajaran project based learning pada mata pelajaran akuntansi XII IPS 5 SMAN 3 Blitar dengan materi “ Jurnal Penyesuaian" yang telah dilaksanakan selama siklus I pada tanggal 7 Februari 2017, 9 Februari 2017, 14 Februari 2017 dan 16 Februari 2017 sebagai berikut.

Kegiatan yang dilakukan pada pertemuan pertama tanggal 7 Februari yaitu setelah guru menjelaskan materi mengenai jurnal penyesuaian yang berkaitan dengan transaksi deferral, guru membagi siswa menjadi 6 kelompok dan menjelaskan rangkaian proyek 1 secara global. Selanjutnya, guru meminta siswa untuk berdiskusi menentukan tempat observasi di perusahaan jasa serta memikirkan garis besar pertanyaan yang akan ditanyakan terkait dengan materi yang sudah dipelajari.

Siswa bersama dengan anggota kelompoknya menuliskan tempat observasi dan daftar pertanyaan untuk selanjutnya didiskusikan dahulu dengan guru agar dapat 
sinkron antara pertanyaan atau rumusan masalah yang sudah dibuat dengan materi yang sudah diajarkan.

Guru bersama dengan siswa secara kolaboratif menentukan jadwal rangkaian proyek, mulai dari kapan proyek dimulai, pelaksanaan untuk terjun lapangan, tempat berkumpul, hingga presentasi dan deadline pengumpulan laporan proyek kelompok.

Tahapan ini dilaksanakan pada pertemuan kedua yaitu tanggal 9 Februari 2017. Guru memastikan kesiapan dan kelengkapan siswa sebelum melakukan observas, masing-masing kelompok melakukan observasi di jenis usaha yang berbeda mulai dari salon, cuci mobil/motor, bengkel, travel, laundry serta service jam dan kacamata, tujuan dibuat berbeda agar masing-masing kelompok nantinya bisa membedakan hasil pengamatan dan lebih banyak informasi yang didapat apabila melakukan observasi di jenis usaha yang berbeda sekaligus juga menghindari saling meniru antara kelompok satu dengan yang lain.

Saat penyelesaian proyek siswa bersama dengan kelompok melakukan penggalian informasi berdasarkan rumusan masalah atau daftar pertanyaan yang sudah dibuat sebelumnya yakni mengenai transaksi deferral.

Pertemuan kedua setelah siswa melakukan pencarian informasi, siswa dan guru berkumpul di tempat yang telah ditentukan yaitu pendopo alun-alun. Siswa dengan kelompoknya masing-masing berdiskusi menyatukan pendapat sekaligus mulai membuat laporan hasil observasi. Pertemuan ketiga siklus I tanggal 14 Februari 2017 siswa bersama dengan kelompoknya secara bergantian harus menyajikan hasil proyek mereka dengan mempresentasikan di depan kelas.

Pertemuan keempat siklus I yaitu tanggal 16 Februari 2016. Kegiatan yang dilakukan pada tahap ini hanya menggali kesan dan pesan siswa mengenai tugas proyek pertama untuk dijadikan tolak ukur dan bila ada kekurangan dapat diperbaiki di proyek berikutnya, pengumpulan makalah dan yang terakhir adalah tes untuk mengetahui hasil belajar setelah adanya penerapan model pembelajaran project based learning.

Minat belajar siswa kelas XI IPS 5 SMAN 3 Blitar yang diamati oleh observer melalui aktivitas siswa untuk setiap kelompoknya setelah diterapkan model pembelajaran project based learning dapat dilihat pada tabel 1 berikut.

Tabel 1 Hasil Observasi Minat Belajar Siswa Siklus I

\begin{tabular}{|l|c|c|c|c|c|c|c|c|}
\hline Minat Belajar/ Tahapan Project & $\mathbf{1}$ & $\mathbf{2}$ & $\mathbf{3}$ & $\mathbf{4}$ & $\mathbf{5}$ & $\mathbf{6}$ & $\mathbf{7}$ & $\mathbf{8}$ \\
\hline Based Learning & $\checkmark$ & $\checkmark$ & $\checkmark$ & & & & & \\
\hline Kenentuan Proyek & - & - & $\checkmark$ & & & & & \\
Kelompok 1 & - & $\checkmark$ & $\checkmark$ & & & & & \\
Kelompok 2 & - & $\checkmark$ & $\checkmark$ & & & & & \\
Kelompok 3 & $\checkmark$ & $\checkmark$ & $\checkmark$ & & & & & \\
Kelompok 5 & - & $\checkmark$ & $\checkmark$ & & & & & \\
Kelompok 6 & & & & & & & & \\
\hline Perencanaan Langkah-Langkah & & & & & & & & \\
Penyelesaian Proyek & $\checkmark$ & $\checkmark$ & $\checkmark$ & $\checkmark$ & & & & \\
Kelompok 1 & - & $\checkmark$ & $\checkmark$ & - & & & & \\
Kelompok 2 & - & $\checkmark$ & $\checkmark$ & $\checkmark$ & & & & \\
Kelompok 3 & - & $\checkmark$ & $\checkmark$ & - & & & & \\
Kelompok 4 & $\checkmark$ & $\checkmark$ & $\checkmark$ & $\checkmark$ & & & & \\
Kelompok 5 & $\checkmark$ & $\checkmark$ & $\checkmark$ & $\checkmark$ & & & & \\
Kelompok 6 & & & & & & & \\
\hline Penyusunan Jadwal & & & & & & & & \\
Pelaksanaan Proyek & & $\checkmark$ & $\checkmark$ & & & & & \\
Kelompok 1 & & $\checkmark$ & $\checkmark$ & & & & & \\
Kelompok 2 & & $\checkmark$ & $\checkmark$ & & & & & \\
Kelompok 3 & & & & & \\
\hline
\end{tabular}




\begin{tabular}{|c|c|c|c|c|c|c|c|}
\hline $\begin{array}{l}\text { Kelompok } 4 \\
\text { Kelompok } 5 \\
\text { Kelompok } 6\end{array}$ & & $\begin{array}{l}\checkmark \\
\checkmark \\
\checkmark\end{array}$ & $\begin{array}{l}\checkmark \\
\checkmark \\
\checkmark\end{array}$ & & & & \\
\hline $\begin{array}{l}\text { Penyelesaian proyek dengan } \\
\text { fasilitasi dan monitoring guru } \\
\text { Kelompok } 1 \\
\text { Kelompok } 2 \\
\text { Kelompok } 3 \\
\text { Kelompok } 4 \\
\text { Kelompok } 5 \\
\text { Kelompok } 6\end{array}$ & $\begin{array}{l}\checkmark \\
\checkmark \\
\checkmark \\
\checkmark \\
\checkmark \\
\checkmark\end{array}$ & $\begin{array}{l}\checkmark \\
\checkmark \\
\checkmark \\
\checkmark \\
\checkmark \\
\checkmark\end{array}$ & & & & & $\begin{array}{l}\checkmark \\
- \\
\checkmark \\
\checkmark \\
\checkmark \\
-\end{array}$ \\
\hline $\begin{array}{l}\text { Penyusunan laporan dan } \\
\text { presentasi/publikasi hasil } \\
\text { proyek } \\
\text { Kelompok } 1 \\
\text { Kelompok } 2 \\
\text { Kelompok } 3 \\
\text { Kelompok } 4 \\
\text { Kelompok } 5 \\
\text { Kelompok } 6\end{array}$ & & & & $\begin{array}{l}\checkmark \\
\checkmark \\
\checkmark \\
\checkmark \\
\checkmark \\
\checkmark\end{array}$ & $\begin{array}{l}\checkmark \\
\checkmark \\
\checkmark \\
\checkmark \\
\checkmark \\
\checkmark\end{array}$ & $\begin{array}{l}\checkmark \\
\checkmark \\
\checkmark \\
\checkmark \\
\checkmark \\
\checkmark\end{array}$ & \\
\hline $\begin{array}{l}\text { Evaluasi proses dan hasil } \\
\text { proyek } \\
\text { Kelompok } 1 \\
\text { Kelompok } 2 \\
\text { Kelompok } 3 \\
\text { Kelompok } 4 \\
\text { Kelompok } 5 \\
\text { Kelompok } 6\end{array}$ & & & & $\begin{array}{l}\checkmark \\
\checkmark \\
\checkmark \\
\checkmark \\
\checkmark \\
\checkmark\end{array}$ & & & \\
\hline
\end{tabular}

Keterangan :

1. Aktivitas Bertanya

2. Aktivitas Mencatat

3. Aktivitas Mendengarkan

4. Aktivitas Diskusi

5. Aktivitas Membuat Laporan

6. Aktivitas Menyajikan Hasil
7. Aktivitas Mengemukakan Fakta atau Prinsip

8. Aktivitas Membuat Keputusan

Dapat dilihat di tabel tersebut saat sintaks pertama minat belajar siswa masih rendah, walaupun semua kelompok sudah nampak aktivitas mendengarkan namun yang tampak bertanya hanya kelompok 1 dan 5 . Lalu kelompok 2 tidak mencatat.

Saat sintaks kedua minat belajar siswa per kelompok belum menemui kemajuan yang berarti. Semua kelompok memang melakukan aktivitas mencatat dan mendengarkan. Saat diminta berdiskusi masih ada kelompok yang bingung dan justru diam saja, kelompok tersebut adalah kelompok 2 dan 4 . Kelompok yang bertanya juga hanya kelompok 1,5 dan 6 .

Aktivitas siswa dari ke 6 kelompok berupa mencatat dan mendengarkan telah nampak pada sintaks project based learning yang ketiga ini.

Aktivitas siswa yang teramati saat sintaks penyelesaian proyek yaitu semua kelompok telah menunjukkan aktivitas bertanya dan mencatat. Namun di aktivitas ke 7 yaitu mengemukakan fakta atau prinsip kelompok dan kelompok 6 belum menunjukkan aktivitas tersebut.

Aktivitas kelompok yang teramati pada sintaks ke 5 yaitu memang semua kelompok melakukan aktivitas diskusi, membuat laporan dan menyajikan hasil. Tidak di aktivitas 8 karena kelompok 2,3,4,6 belum dapat membuat keputusan.

Aktivitas yang tampak pada sintaks terakhir dari project based learning yaitu siswa menyampaikan pesan dan kesan selama kegiatan proyek 1 yang sudah dilakukan. Hal itu juga nantinya akan dijadikan dasar perbaikan bagi guru untuk 
pelaksanaan proyek selanjutnya. Siswa mengumpulkan hasil proyek berupa makalah kelompok dan melakukan tes evaluasi untuk mengetahui tingkat pemahaman siswa.

Berdasarkan hasil yang diperoleh tersebut siswa belum dikatakan mempunyai minat atau antusias dalam belajar akuntansi melalui penugasan proyek pada siklus I. $\mathrm{Hal}$ tersebut bisa dilihat dari aktivitas siswa yang masih sangat kurang saat kegiatan pembelajaran berlangsung. Hasil belajar siswa kelas XI IPS 5 SMAN 3 Blitar setelah diterapkan model pembelajaran project based learning pada mata pelajaran akuntansi selama empat kali pertemuan pada siklus I mengalami peningkatan dari sebelum diterapkan model tersebut. Hasil belajar pra tindakan diperoleh dari nilai UH sebelumnya.

Berdasarkan hasil dari nilai pra tindakan atau nilai yang didapatkan dari guru mata pelajaran siswa yang tuntas sebelum tindakan sebanyak 7 siswa dan siswa yang tidak tuntas sebanyak 21 siswa dan berdasarkan hasil tes setelah tindakan siswa yang tuntas sebanyak 17 siswa dan siswa yang tidak tuntas sebanyak 11 siswa dengan nilai rata-rata . Dari hasil belajar yang didapat dari nilai pra tindakan dan tes setelah dilakukan tindakan dapat dilihat bahwa hasil belajar siswa terjadi peningkatan yang belum signifikan.

Tabel 2 Ketuntasan Belajar Siswa pada Siklus I

\begin{tabular}{clcc}
\hline \multicolumn{1}{c}{ Tes } & $\begin{array}{c}\text { Ketuntasan } \\
\text { Belajar }\end{array}$ & $\sum$ Siswa & $\begin{array}{c}\sum \text { Seluruh } \\
\text { Siswa }\end{array}$ \\
\hline Pra Tindakan & Tuntas & 7 & 28 \\
& Tidak Tuntas & 21 & 28 \\
Tes Evaluasi & Tuntas & 17 & 28 \\
& Tidak Tuntas & 11 & 28 \\
\hline
\end{tabular}

Berdasarkan tabel 2 dapat diketahui bahwa persentase keberhasilan belajar siswa masih $\leq 70 \%$. Sedangkan kriteria keberhasilan dari penelitian yaitu hasil perhitungan belajar siswa harus menunjukkan $\geq 70 \%$ siswa berada dalam kategori minimal baik. Dapat disimpulkan bahwa pada siklus I belum terpenuhi sehingga tindakan akan diulang pada siklus II.

Berdasarkan paparan data dalam tindakan siklus II, dapat diketahui hasil yang diperoleh adalah sebagai berikut. Penerapan model pembelajaran project based learning pada mata pelajaran akuntansi kelas XI IPS 5 dengan materi "Jurnal Penyesuaian" yang telah dilaksanakan selama siklus II pada tanggal 21 Februari 2017, 23 Februari 2017, 28 Februari 2017 dan 2 Maret 2017 sebagai berikut.

Pertemuan pertama tanggal 21 Februari yaitu setelah guru menjelaskan materi mengenai jurnal penyesuaian yang berkaitan dengan transaksi akrual, guru meminta siswa berkumpul dengan kelompoknya dan menjelaskan rangkaian proyek 2 secara global. Selanjutnya, memikirkan rumusan masalah atau daftar pertanyaan yang akan ditanyakan terkait dengan materi jurnal penyesuaian transaksi akrual.

Saat ini guru memastikan siswa berdiskusi dan benar-benar menyiapkan daftar pertanyaan atau rumusan masalah yang akan ditanyakan tidak seperti pada proyek 1 masih ada kelompok yang beberapa pertanyaannya kurang sinkron dengan materi. Guru juga memotivasi siswa untuk dapat kompak dan dapat saling bekerja sama di rangkaian proyek 2 ini sehingga nantinya hasil yang didapat juga akan maksimal.

Guru bersama dengan siswa secara kolaboratif menentukan jadwal rangkaian proyek, mulai dari kapan proyek dimulai, pelaksanaan untuk terjun lapangan, tempat berkumpul, hingga presentasi dan deadline pengumpulan laporan proyek kelompok.

Tahapan ini dilaksanakan pada pertemuan kedua yaitu tanggal 23 Februari 2017. Siswa bersama dengan kelompoknya harus melakukan penggalian informasi berdasarkan rumusan masalah atau daftar pertanyaan yang sudah dibuat sebelumnya 
Vol. 1 No. 1, Oktober 2017

yakni mengenai transaksi akrual di tempat atau perusahaan yang sama seperti di proyek 1.

Pertemuan kedua setelah siswa melakukan pencarian informasi, siswa dan guru berkumpul di tempat yang telah ditentukan yaitu pendopo alun-alun. Siswa dengan kelompoknya masing-masing berdiskusi menyatukan pendapat sekaligus mulai membuat laporan hasil observasi. Pertemuan ketiga siklus II tanggal 28 Februari 2017 siswa bersama dengan kelompoknya secara bergantian harus menyajikan hasil proyek mereka dengan mempresentasikan di depan kelas.

Pertemuan keempat siklus II yaitu tanggal 2 Maret 2016. Kegiatan yang dilakukan pada tahap ini hanya menggali kesan dan pesan siswa mengenai proyek yang sudah dikerjakan selama ini, pengumpulan makalah dan yang terakhir adalah tes untuk mengetahui hasil belajar setelah adanya penerapan model pembelajaran project based learning.

Minat belajar siswa kelas XI IPS 5 SMAN 3 Blitar yang diamati oleh observer melalui aktivitas siswa untuk setiap kelompoknya setelah diterapkan model pembelajaran project based learning dapat dilihat pada tabel 3 berikut

Tabel 3 Hasil Observasi Minat Belajar Siklus II

\begin{tabular}{|c|c|c|c|c|c|c|c|c|}
\hline $\begin{array}{l}\text { Minat Belajar/ Tahapan } \\
\text { Project Based Learning }\end{array}$ & 1 & 2 & 3 & 4 & 5 & 6 & 7 & 8 \\
\hline $\begin{array}{l}\text { Penentuan Proyek } \\
\text { Kelompok } 1 \\
\text { Kelompok } 2 \\
\text { Kelompok } 3 \\
\text { Kelompok } 4 \\
\text { Kelompok } 5 \\
\text { Kelompok } 6\end{array}$ & $\begin{array}{l}\checkmark \\
- \\
\checkmark \\
\checkmark \\
\checkmark \\
-\end{array}$ & $\begin{array}{l}\checkmark \\
\checkmark \\
\checkmark \\
\checkmark \\
\checkmark \\
\checkmark\end{array}$ & $\begin{array}{l}\checkmark \\
\checkmark \\
\checkmark \\
\checkmark \\
\checkmark \\
\checkmark\end{array}$ & & & & & \\
\hline $\begin{array}{l}\text { Perencanaan Langkah- } \\
\text { Langkah Penyelesaian } \\
\text { Proyek } \\
\text { Kelompok } 1 \\
\text { Kelompok } 2 \\
\text { Kelompok } 3 \\
\text { Kelompok } 4 \\
\text { Kelompok } 5 \\
\text { Kelompok } 6 \\
\end{array}$ & $\begin{array}{l}\checkmark \\
- \\
\checkmark \\
\checkmark \\
\checkmark \\
\checkmark\end{array}$ & $\begin{array}{l}\checkmark \\
\checkmark \\
\checkmark \\
\checkmark \\
\checkmark \\
\checkmark\end{array}$ & $\begin{array}{l}\checkmark \\
\checkmark \\
\checkmark \\
\checkmark \\
\checkmark \\
\checkmark\end{array}$ & $\begin{array}{l}\checkmark \\
- \\
\checkmark \\
\checkmark \\
\checkmark \\
\checkmark\end{array}$ & & & & \\
\hline $\begin{array}{l}\text { Penyusunan Jadwal } \\
\text { Pelaksanaan Proyek } \\
\text { Kelompok } 1 \\
\text { Kelompok } 2 \\
\text { Kelompok } 3 \\
\text { Kelompok } 4 \\
\text { Kelompok } 5 \\
\text { Kelompok } 6 \\
\end{array}$ & & $\begin{array}{l}\checkmark \\
\checkmark \\
\checkmark \\
\checkmark \\
\checkmark \\
\checkmark\end{array}$ & $\begin{array}{l}\checkmark \\
\checkmark \\
\checkmark \\
\checkmark \\
\checkmark \\
\checkmark\end{array}$ & & & & & \\
\hline $\begin{array}{l}\text { Penyelesaian proyek dengan } \\
\text { fasilitasi dan monitoring } \\
\text { guru } \\
\text { Kelompok } 1 \\
\text { Kelompok } 2 \\
\text { Kelompok } 3 \\
\text { Kelompok } 4 \\
\text { Kelompok } 5 \\
\text { Kelompok } 6\end{array}$ & $\begin{array}{l}\checkmark \\
\checkmark \\
\checkmark \\
\checkmark \\
\checkmark \\
\checkmark\end{array}$ & $\begin{array}{l}\checkmark \\
\checkmark \\
\checkmark \\
\checkmark \\
\checkmark \\
\checkmark\end{array}$ & & & & & $\begin{array}{l}\checkmark \\
\checkmark \\
\checkmark \\
\checkmark \\
\checkmark \\
\checkmark\end{array}$ & \\
\hline
\end{tabular}




\begin{tabular}{|c|c|c|c|c|}
\hline & & & & \\
\hline $\begin{array}{l}\text { Penyusunan laporan dan } \\
\text { presentasi/publikasi hasil } \\
\text { proyek } \\
\text { Kelompok } 1 \\
\text { Kelompok } 2 \\
\text { Kelompok } 3 \\
\text { Kelompok } 4 \\
\text { Kelompok } 5 \\
\text { Kelompok } 6 \\
\end{array}$ & $\begin{array}{l}\checkmark \\
\checkmark \\
\checkmark \\
\checkmark \\
\checkmark \\
\checkmark\end{array}$ & $\begin{array}{l}\checkmark \\
\checkmark \\
\checkmark \\
\checkmark \\
\checkmark \\
\checkmark\end{array}$ & $\begin{array}{l}\checkmark \\
\checkmark \\
\checkmark \\
\checkmark \\
\checkmark \\
\checkmark\end{array}$ & $\begin{array}{l}\checkmark \\
\checkmark \\
\checkmark \\
\checkmark \\
\checkmark \\
\checkmark \\
\checkmark\end{array}$ \\
\hline $\begin{array}{l}\text { Evaluasi proses dan hasil } \\
\text { proyek } \\
\text { Kelompok } 1 \\
\text { Kelompok } 2 \\
\text { Kelompok } 3 \\
\text { Kelompok } 4 \\
\text { Kelompok } 5 \\
\text { Kelompok } 6\end{array}$ & $\begin{array}{l}\checkmark \\
\checkmark \\
\checkmark \\
\checkmark \\
\checkmark\end{array}$ & & & \\
\hline
\end{tabular}

\section{Keterangan :}

1. Aktivitas Bertanya

2. Aktivitas Mencatat

3. Aktivitas Mendengarkan

4. Aktivitas Diskusi

5. Aktivitas Membuat Laporan

6. Aktivitas Menyajikan Hasil
7. Aktivitas Mengemukakan Fakta atau Prinsip

8. Aktivitas Membuat Keputusan

Dapat dilihat di tabel tersebut saat sintaks pertama minat belajar siswa maeningkat dari siklus I. Hampir semua kelompok melakukan aktivitas hanya kelompok 2 dan 6 yang tidak bertanya. Sedangkan kelompok lain sudah terlihat aktivitas mendengarkan, bertanya dan mencatat.

Saat sintaks kedua minat belajar siswa per kelompok belum sudah mengalami kenaikan yang signifikan. Semua kelompok kecuali kelompok 2 melakukan aktivitas mencatat, mendengarkan, mendengarkan dan berdiskusi.

Aktivitas siswa dari ke 6 kelompok berupa mencatat dan mendengarkan telah nampak pada sintaks project based learning yang ketiga ini. Aktivitas siswa yang teramati saat sintaks penyelesaian proyek yaitu semua kelompok telah menunjukkan aktivitas bertanya, mencatat dan kesemuanya sudah menunjukkan aktivitas mengemukakan fakta atau prinsip. Aktivitas kelompok yang teramati pada sintaks ke 5 yaitu memang semua kelompok melakukan aktivitas diskusi, membuat laporan,menyajikan hasil serta sudah dapat membuat keputusan. Aktivitas yang tampak pada sintaks terakhir dari project based learning yaitu siswa menyampaikan pesan dan kesan selama kegiatan proyek yang sudah dilakukan. Siswa mengumpulkan hasil proyek berupa makalah kelompok dan melakukan tes evaluasi untuk mengetahui tingkat pemahaman siswa.

Hasil belajar siswa kelas XI IPS 5 SMAN 3 Blitar setelah diterapkan model pembelajaran problem based learning pada mata pelajaran akuntansi selama empat kali pertemuan pada siklus II mengalami peningkatan dari siklus I.

Berdasarkan hasil dari nilai yang didapatkan pada tes dan nilai proyek (makalah kelompok) yang dilakukan pada siklus I siswa yang tuntas sebanyak 17 siswa dan siswa yang tidak tuntas sebanyak 11 siswa dan berdasarkan hasil tes setelah tindakan pada siklus II siswa yang tuntas sebanyak 21 siswa dan siswa yang tidak tuntas sebanyak 7 siswa. Dari hasil belajar yang didapat dapat dilihat bahwa hasil belajar siswa terjadi peningkatan atau dapat dikatakan bahwa hasil belajar siswa pada siklus II dalam kategori baik. 
Tabel 4 Ketuntasan Belajar Siswa pada Siklus I dan II

\begin{tabular}{llcc}
\hline \multicolumn{1}{c}{ Tes } & \multicolumn{1}{c}{$\begin{array}{c}\text { Ketuntasan } \\
\text { Belajar }\end{array}$} & $\sum$ Siswa & $\begin{array}{c}\sum \text { Seluruh } \\
\text { Siswa }\end{array}$ \\
\hline Pra Tindakan & Tuntas & 7 & 28 \\
Tes Evaluasi & Tidak Tuntas & 21 & 28 \\
Siklus I & Tidantas Tuntas & 17 & 28 \\
Tes Evaluasi & Tuntas & 11 & 28 \\
Siklus II & Tidak Tuntas & 21 & 28 \\
\hline
\end{tabular}

Berdasarkan hasil belajar siswa yang diperoleh dari proyek kelompok dan tes evaluasi yang dilakukan setelah tindakan pada siklus II, hanya terdapat 7 siswa masih belum tuntas atau masih dibawah KKM yaitu 70 dan 21 siswa nilai sudah mencapai target. Dapat disimpulkan bahwa kegiatan pada siklus II sudah terpenuhi sehingga tindakan dihentikan pada siklus II.

\section{PEMBAHASAN}

Proses pembelajaran dengan model pembelajaran project based learning pada tiap siklus minat belajar siswa sudah mengalami peningkatan. Banyak siswa yang telah memiliki antusiasme dan semangat untuk belajar, hal ini dibuktikan dengan meningkatnya aktivitas siswa di kelas. Banyak siswa yang sudah tidak takut bertanya, baik itu saat guru menyampaikan materi maupun saat diberikan permasalahan. Aktivitas yang muncul pada semua tahapan pembelajaran berbasis proyek menunjukkan adanya minat atau ketertarikan siswa dalam bentuk yang beragam. Meningkatnya aktivitas tersebut menunjukkan tumbuhnya minat siswa terhadap pembelajaran berbasis proyek. Kondisi saat pembelajaran berlangsung juga mengalami peningkatan. Jika sebelumnya siswa cenderung pasif hanya mendengarkan guru menyampaikan materi, pada pembelajaran yang diterapkan model project based learning siswa menjadi aktif dan dapat mengkonstruk pengetahuan mereka dengan cara belajar diluar lingkungan sekolah bersama dengan kelompoknya masing-masing.

Hasil penelitian ini sejalan dengan hasil penelitian yang dilakukan oleh Dedy (2013) yaitu model pembelajaran berbasis proyek dapat meningkatkan motivasi belajar siswa karena siswa mampu melakukan penelitian pada dunia nyata dan belajar pada orang yang memiliki kecakapan relevan.

Hal ini sesuai dengan teori yang dikemukakan oleh Hidi \& Harackiewicz (2000) , siswa yang tertarik pada apa yang mereka pelajari menunjukkan prestasi akademik yang lebih tinggi dan lebih mungkin mengingat materi tersebut dalam jangka panjang. Begitu juga dengan penelitian yang dilakukan oleh Dedy Kurnianto (2013) "Implementasi Strategi Pembelajaran Kreatif Produktif dengan Model Pembelajaran Berbasis Proyek untuk Meningkatkan Motivasi Belajar Siswa Kelas X Akuntansi 2 SMK YPKK 1 Sleman" . Hasil dari penelitian Hasil penelitian menunjukkan bahwa terjadi peningkatan skor motivasi belajar akuntansi dari sebelum implementasi strategi pembelajaran kreatif produktif dengan model pembelajaran berbasis proyek.

Selanjutnya melaksanakan proses pembelajaran dengan model pembelajaran project based learning pada tiap siklus hasil belajar siswa sudah mengalami peningkatan. Hal tersebut dapat dilihat saat pembelajaran berlangsung siswa dapat menjawab pertanyaan yang diberikan oleh guru. Selain itu siswa juga berpartisipasi penuh saat proses pembelajaran, karena dalam model ini siswa dituntut agar dapat mengkonstruk pengetahuan mereka dan berusaha untuk menemukan alternatif pemecahan masalah yang ada du dunia nyata dengan melakukan observasi kecil di perusahaan jasa mengenai materi jurnal penyesuaian untuk transaksi pos deferral dan akrual. Setiap anggota kelompok memiliki tanggung jawab masing-masing 
dalam mengerjakan tugas proyek, sehingga tidak ada siswa yang dianggap menumpang kepada anggota kelompok lainnya.

Sesuai dengan teori yang dikemukakan oleh Dimyati dan Mudjiono (2006:20) mengungkapkan bahwa "hasil belajar merupakan puncak proses belajar, sedangkan belajar adalah seperangkat proses kognitif yang mengubah sifat stimulus lingkungan, dengan melewati pengolahan informasi menjadi kapabilitas baru". Begitu juga dengan pendapat Sardirman (2007:84) "Hasil belajar atau prestasi belajar akan menjadi optimal kalau ada motivasi. Semakin tepat motivasi yang diberikan, akan semakin berhasil pula pelajaran itu". Jadi hasil belajar yang diperoleh siswa XI IPS 5 SMAN 3 Blitar ini merupakan nilai yang diperoleh siswa setelah guru menerapkan model project based learning.

\section{KESIMPULAN}

Berdasarkan hasil penelitian dan pembahasan yang telah diuraikan sebelumnya, diperoleh kesimpulan sebagai berikut: (1) Terdapat peningkatan minat belajar siswa kelas XI IPS 5 SMA Negeri 3 Blitar dengan menerapkan model Project Based Learning. Hal ini terbukti dari peningkatan aktivitas siswa saat mengikuti rangkaian pembelajaran. Yaitu siswa sudah berani bertanya, mendengarkan penjelasan dari guru maupun saat penggalian informasi dengan narasumber, mencatat hal-hal yang dirasa perlu, saling berdiskusi antar anggota kelompok untuk menyelesaikan tugas proyek, berkolaborasi dalam membuat laporan proyek, menyajikan hasil proyek secara berkelompok, serta dapat mengemukakan fakta yang didapat di lapangan untuk selanjutnya bisa menarik kesimpulan. Meningkatnya aktivitas tersebut berdampak pada meningkatnya minat belajar siswa pada kelas XI IPS 5. (2) Hasil belajar siswa kelas XI IPS 5 SMA Negeri 3 Blitar meningkat setelah pelaksanaan model Project Based Learning. Ketuntasan belajar klasikal pada siklus I sebesar $61 \%$ dan untuk siklus II memperoleh ketuntasan belajar klasikal sebesar $71 \%$.

\section{SARAN}

Dengan memperhatikan hasil temuan dalam penelitian ini, maka dalam kesempatan ini penulis bermaksud menyampaikan saran-saran. (1) Diharapkan saat penggunaan model pembelajaran ini guru juga dapat mengantisipasi jika saat pelaksanaan proyek siswa tidak bisa dipantau secara berkelompok. Bisa dengan mengirimkan video wawancara ataupun rekaman suara saat menggali informasi di tempat observasi. (2) Kepada para guru jika akan menggunakan model Project Based Learning dalam proses pembelajaran harus bisa mematangkan konsep dan materi kepada siswa, sehingga siswa nantinya tidak bingung saat harus mengkaitkan konsep dengan kehidupan nyata saat pengerjaan proyek. (3) Diharapkan untuk penelitian selanjutnya agar dapat menuliskan secara rinci mengenai tugas proyek beserta langkah-langkah yang harus dilakukan oleh siswa.(4) Peneliti selanjutnya juga diharapkan dapat memperbaiki format laporan hasil proyek agar lebih merujuk langsung pada tahapan model pembelajaran Project Based Learning.

\section{DAFTAR RUJUKAN}

Abidin, Yunus. 2014. Desain Sisitem Pembelajaran dalam Konteks Kurikulum 2013. Bandung: PT Refika Aditama.

Dimyati dan Moedjiono. 2009. Belajar dan Pembelajaran. Jakarta: Rineka Cipta.

Harsono. 2006. Kearifan dalam Transformasi Pembelajaran dari Teacher-Centered ke Student-Centered Learning. Jurnal Penelitian Kedokteran dan Profesi Kesehatan, 3(1), (Online), (http://luk.staff.ug,.ac.id/), diakses 8 Januari 2016.

Hidi, S., \& Harackiewicz, J.M. 2000. Motivating The Academically Unmotivated: A Critical Issue for The 21st century Review of Educational Research.

Ormrod, Jeanne Ellis. 2009. Psikologi Pendidikan: Membantu Siswa Tumbuh dan Berkembang (Rikard Rahmat, Ed.). Jakarta: Erlangga. 
Vol. 1 No. 1, Oktober 2017

Sardirman, A. M. 2007. Interaksi dan Motivasi Belajar Mengajar. Jakarta: Rajawali Grafindo Persada.

Slameto. 2010. Belajar dan Faktor-faktor yang Mempengaruhinya. Jakarta: Rineka Cipta.

Sugiyono. 2009. Metode Penelitian Bisnis (Pendekatan Kuantitatif, Kualitatif, dan $R \& D)$. Bandung: Alfabeta.

Sukmadinata, Nana Syaodih. 2004. Metode Penelitian Pendidikan. Bandung: Remaja Rosdakarya. 